\title{
Spectrophotometric Determination of Molybdenum(VI) Using Isothipendyl Hydrochloride and Pipazethate Hydrochloride in Alloy Steels and Soil Samples
}

\author{
Mahaveer B. Melwanki, Jaldappa Seetharamappa, ${ }^{\dagger}$ and Saraswati P. Masti \\ Department of Chemistry, Karnatak University, Dharwad-580 003, India
}

(Received March 19, 2001; Accepted June 11, 2001)

\begin{abstract}
Molybdenum is commercially important in metallurgical and agricultural laboratories. Besides its widespread industrial uses, molybdenum is an essential trace element required by both plants and animals. ${ }^{1}$ It is, however, harmful to both plants and animals at high concentrations. ${ }^{2}$ Deficiency diseases in livestock have been recorded when soil molybdenum levels were below $1 \mu \mathrm{g} \mathrm{g}^{-1}$. The increasing use of chemicals in agriculture requires more profound studies on the determination of microelements in soils and their migration. So molybdenum determination is of great interest to analytical chemists, particularly to soil and environmental chemists. The standard method available for the determination of molybdenum in soil is tedious and lengthy. ${ }^{3}$ In this method, separation of chromium, titanium and reduction of vanadium using stannous chloride is necessary prior to molybdenum determination. The method of determining molybdenum using thiocyanate and stannous chloride has several disadvantages, such as variation of absorbances with respect to the concentrations of thiocyanate, stannous chloride and acid; low sensitivity. Furthermore, other elements viz., Re, V, W, U, Cr, which in their lower oxidation states formed thiocyanate complexes, are also reduced and interfere with the determination of molybdenum. ${ }^{4}$ Hence, a milder reductant which reduces $\mathrm{Mo}(\mathrm{VI})$ to $\mathrm{Mo}(\mathrm{V})$ quantitatively is desirable; ascorbic acid used in the present study serves the purpose. In the present investigation we are reporting two simple, adequately sensitive and accurate extractive spectrophotometric methods for the determination of $\mathrm{Mo}(\mathrm{VI})$ in alloy steels and soil samples using isothipendyl hydrochloride (IPH) and pipazethate hydrochloride (PPZ). The methods are based on the formation of chloroform-soluble mixed-ligand complexes of $\mathrm{Mo}(\mathrm{V})$ with thiocyanate and IPH or PPZ in hydrochloric acid medium. The chromogens formed in the proposed methods are more stable (more than $24 \mathrm{~h}$ ) compared to that reported earlier ${ }^{5}\left(\begin{array}{ll}1 & \mathrm{~h}\end{array}\right)$ and also have higher molar absorptivity $\left(3.28-4.0 \times 10^{4}\right)$ than those of the reported methods $^{6-9}\left(0.97-9.6 \times 10^{3}\right)$. The methods are free from interference by a large number of metal ions unlike the reported methods. ${ }^{8-10}$ Thus the extraction of ternary complexes with chloroform led to high sensitivity, selectivity and stability compared with the methods described previously. ${ }^{5-10}$
\end{abstract}

\footnotetext{
$\doteqdot$ To whom correspondence should be addressed.

E-mail: jseetharam@yahoo.com; j_seetharam @ rediffmail.com
}

\section{Experimental}

\section{Apparatus}

A Hitachi (Model U-2001) UV-visible spectrophotometer with $1 \mathrm{~cm}$ matched quartz cells was used for the absorbance measurements. Elemental analysis of the complex was performed on a Thermoquest CHN analyzer (Model EA 1110 $\mathrm{CHN}$ ) and a Nicolet FTIR spectrophotometer (Model Impact410) was used for recording the IR spectrum.

\section{Reagents and samples}

All the chemicals used were of analytical or pharmaceutical grade and quartz-processed high-purity water was used throughout.

A stock solution of $\mathrm{Mo}(\mathrm{VI})$ was prepared using ammonium molybdate tetrahydrate (AR) in $100 \mathrm{ml}$ distilled water and was standardized by a reported method. ${ }^{11}$ It was diluted to give a standard solution containing $100 \mu \mathrm{g} \mathrm{ml}^{-1}$ of $\mathrm{Mo}(\mathrm{VI})$. Two $0.5 \%$ solutions, one of IPH and one of PPZ, were prepared separately in distilled water and were stored in amber-colored bottles in a refrigerator. Aqueous solutions of $20 \% \mathrm{NH}_{4} \mathrm{SCN}$ and 5\% ascorbic acid were prepared in distilled water. A $10 \mathrm{M} \mathrm{HCl}$ was also prepared. Solutions of diverse ions of suitable concentrations were prepared using AR grade reagents.

\section{Determination of $M o(V I)$}

To a known volume of Mo(VI) solution, taken in a series of separating funnels, were added $2 \mathrm{ml}$ of $10 \mathrm{M} \mathrm{HCl}, 2$ or $3 \mathrm{ml}$ of $20 \% \mathrm{NH}_{4} \mathrm{SCN}$ for IPH or PPZ and 5 or $6 \mathrm{ml}$ of $5 \%$ ascorbic acid for IPH or PPZ. The mixture was set aside for $20 \mathrm{~min}$ and then to it were added $6 \mathrm{ml}$ of IPH or PPZ. Then the mixture was diluted to $20 \mathrm{ml}$ to maintain $\mathrm{HCl}$ concentration at $1 \mathrm{M}$. Ten milliliters of chloroform was added and the container was shaken well. The two phases were allowed to separate and the chloroform layer was passed through anhydrous $\mathrm{Na}_{2} \mathrm{SO}_{4}$. The absorbances of the orange-red colored species were measured at $461 \mathrm{~nm}$ for IPH or at $465 \mathrm{~nm}$ for PPZ against the corresponding reagent blank. The amount of $\mathrm{Mo}(\mathrm{VI})$ in the sample solution was deduced from the calibration curve.

\section{Analysis of molybdenum in alloy steels}

About $0.5 \mathrm{~g}$ of alloy steel was weighed accurately, treated with aqua regia repeatedly until the sample was dissolved completely and then heated to fumes of oxides of nitrogen. 


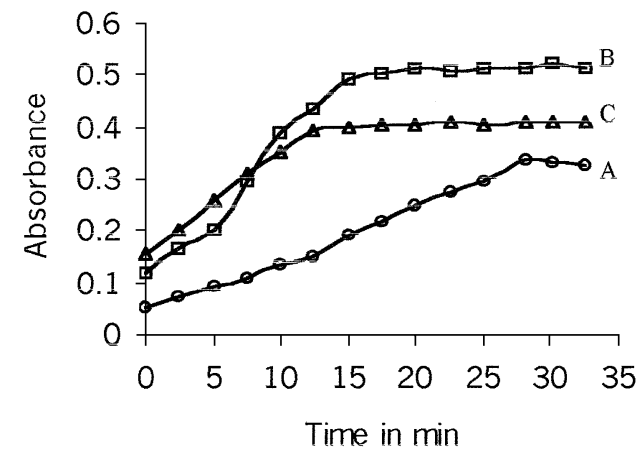

Fig. 1 Effect of $\mathrm{HCl}$ concentration and standing time intervals: $\mathrm{HCl}$ concentration at A, $0.75 \mathrm{M} ; \mathrm{B}, 1 \mathrm{M}$ and $\mathrm{C}, 1.25 \mathrm{M}$.

After it was cooled, $10 \mathrm{ml}$ of concentrated $\mathrm{H}_{2} \mathrm{SO}_{4}$ was added and evaporated almost to dryness. We repeated the evaporation and $\mathrm{H}_{2} \mathrm{SO}_{4}$ treatment three times to remove all the $\mathrm{HNO}_{3}$. Finally, $20 \mathrm{ml}$ of $10 \mathrm{M} \mathrm{HCl}$ was added to the residue and any insoluble material was filtered off. Then we diluted the solution to $100 \mathrm{ml}$ in a calibrated flask with distilled water. Ten milliliters of the stock solution were further diluted to $100 \mathrm{ml}$ with $2 \mathrm{M} \mathrm{HCl}$. To an aliquot solution $(0.5-2.0 \mathrm{ml})$ taken in a separating funnel was added $\mathrm{HCl}(1.9-1.6 \mathrm{ml}$ of $10 \mathrm{M})$, followed by 2 or $3 \mathrm{ml}$ of $20 \% \mathrm{NH}_{4} \mathrm{SCN}$ and 5 or $6 \mathrm{ml}$ of $5 \%$ ascorbic acid for IPH or PPZ. It was set aside for $20 \mathrm{~min}$; then $6 \mathrm{ml}$ of IPH or PPZ was added and the mixture was diluted to $20 \mathrm{ml}$ with distilled water to maintain the overall acid concentration at $1 \mathrm{M}$. The ternary complex formed was extracted into chloroform and the amount of molybdenum was deduced from the calibration curve.

\section{Analysis of soil samples}

Two grams of soil sample were placed in a platinum crucible containing about $7-8 \mathrm{~g}$ of anhydrous $\mathrm{Na}_{2} \mathrm{CO}_{3}$ and the contents were mixed thoroughly. The mixture was heated gently to about $500^{\circ} \mathrm{C}$ to burn off the soil organic matter during the first 5 to $10 \mathrm{~min}$ in an oxidizing atmosphere, to avoid the possibility of molybdenum loss, before the charge was fused. It was further heated to $1000-1100^{\circ} \mathrm{C}$ in an electric furnace till fusion was over. The melt was cooled and then transferred into a beaker by washing repeatedly with distilled water, and then filtered through a piece of Whatman filter paper No. 40. An aliquot solution $(1-2 \mathrm{ml})$ was taken and neutralized with $10 \mathrm{M} \mathrm{HCl}$. Amounts of $\mathrm{NH}_{4} \mathrm{SCN}$, ascorbic acid and IPH or PPZ were added as mentioned earlier while maintaining the overall acid concentration to be $1 \mathrm{M}$ with $\mathrm{HCl}$. The ternary complex developed was extracted into chloroform and the amount of molybdenum was determined from the calibration curve.

\section{Results and Discussion}

Preliminary investigations have shown that IPH or PPZ reacts with $\mathrm{Mo}(\mathrm{V})$ obtained by ascorbic acid reduction of $\mathrm{Mo}(\mathrm{VI})$ in the presence of $\mathrm{HCl}$ containing thiocyanate at room temperature to form chloroform soluble orange-red ternary complexes having maximum absorbance at $461 \mathrm{~nm}$ for IPH or at $465 \mathrm{~nm}$ for PPZ. The optimum reaction conditions for quantitative determination of the mixed-ligand complexes were established via a number of preliminary studies. The effect of acids on the
Table 1 Tolerance limits of diverse ions in the determination of molybdenum(VI)

\begin{tabular}{|c|c|c|c|c|c|}
\hline \multirow{2}{*}{$\begin{array}{l}\text { Ion or } \\
\text { species } \\
\text { added }\end{array}$} & \multicolumn{2}{|c|}{$\begin{array}{l}\text { Tolerance limit/ } \\
\qquad \mu \mathrm{g} \mathrm{ml}^{-1}\end{array}$} & \multirow{2}{*}{$\begin{array}{l}\text { Ion or } \\
\text { species } \\
\text { added }\end{array}$} & \multicolumn{2}{|c|}{$\begin{array}{c}\text { Tolerance limit/ } \\
\qquad \mu \mathrm{g} \mathrm{ml}^{-1}\end{array}$} \\
\hline & IPH & PPZ & & IPH & PPZ \\
\hline $\mathrm{Ni}(\mathrm{II})$ & 7500 & 7000 & $\operatorname{Th}(\mathrm{IV})$ & 1800 & 2000 \\
\hline $\mathrm{Cu}(\mathrm{II})$ & 250 & 250 & $\mathrm{~W}(\mathrm{VI})$ & 40 & 45 \\
\hline $\mathrm{Co}(\mathrm{II})$ & 4000 & 4200 & $\mathrm{U}(\mathrm{VI})$ & 45 & 45 \\
\hline $\operatorname{Mn}(\mathrm{II})$ & 2400 & 2500 & $\mathrm{Cd}(\mathrm{II})$ & 5000 & 5200 \\
\hline $\mathrm{Cr}(\mathrm{VI})$ & 600 & 500 & $\mathrm{Zr}(\mathrm{IV})$ & 150 & 150 \\
\hline $\mathrm{V}(\mathrm{V})$ & 1500 & 1300 & Fluoride & 2500 & 2200 \\
\hline $\mathrm{Na}(\mathrm{I})$ & 6000 & 5500 & Chloride & 8000 & 7500 \\
\hline $\mathrm{K}(\mathrm{I})$ & 5000 & 5000 & Sulfate & 4000 & 4200 \\
\hline $\mathrm{Ca}(\mathrm{II})$ & 4500 & 4000 & Oxalate & 3000 & 2800 \\
\hline $\operatorname{Mg}(\mathrm{II})$ & 4500 & 4000 & Nitrate & 1800 & 2000 \\
\hline $\mathrm{Fe}(\mathrm{III})$ & 7000 & 7500 & Citrate & 5000 & 6000 \\
\hline $\mathrm{Hg}(\mathrm{II})$ & 2500 & 2200 & Acetate & 5000 & 5500 \\
\hline $\mathrm{Pb}(\mathrm{II})$ & 3000 & 2800 & Tartarate & 4500 & 4000 \\
\hline $\mathrm{Al}(\mathrm{III})$ & 4200 & 4500 & Bromide & 1200 & 1500 \\
\hline $\mathrm{Zn}(\mathrm{II})$ & 4500 & 4000 & Phosphate & 3000 & 3500 \\
\hline
\end{tabular}

formation of complexes has been studied using $\mathrm{HCl}, \mathrm{H}_{2} \mathrm{SO}_{4}$, $\mathrm{H}_{3} \mathrm{PO}_{4}$ and $\mathrm{CH}_{3} \mathrm{COOH}$. As $\mathrm{HNO}_{3}$ oxidized the ligand, it was not used for the study. It was observed that the color intensity of the complex was slow in $\mathrm{H}_{3} \mathrm{PO}_{4}$ and $\mathrm{CH}_{3} \mathrm{COOH}$. It was also noticed that the reduction of $\mathrm{Mo}(\mathrm{VI})$ to $\mathrm{Mo}(\mathrm{V})$ by ascorbic acid was slow below $1 \mathrm{M} \mathrm{HCl}$. The effect of $\mathrm{HCl}$ concentration and standing time intervals for completion of the reaction of IPH are given (Fig. 1). The effects of different amounts of $\mathrm{NH}_{4} \mathrm{SCN}(0.5$ $-4 \mathrm{ml})$, ascorbic acid $(2-8 \mathrm{ml})$ and IPH or PPZ $(2-8 \mathrm{ml})$ were investigated on the formation of ternary complexes of $\mathrm{Mo}(\mathrm{V})$. The color development was slow when the volume of $\mathrm{NH}_{4} \mathrm{SCN}$ was less than 1.5 or $2.5 \mathrm{ml}$ for IPH or PPZ, while quantitative extraction of the ternary complex was not achieved with less than $6 \mathrm{ml}$ of IPH or PPZ. It was also noticed that an excess of the reagents had no effect on the sensitivity or stability of the complexes. However, 2 and $3 \mathrm{ml}$ of $\mathrm{NH}_{4} \mathrm{SCN}$ respectively for IPH and PPZ and $6 \mathrm{ml}$ of IPH or PPZ were used to ensure complete formation of the complex. A volume of $5 \mathrm{ml}$ of ascorbic acid was found to be sufficient for the quantitative reduction of $\mathrm{Mo}(\mathrm{VI})$ to $\mathrm{Mo}(\mathrm{V})$; excess of ascorbic acid had no effect either on the stability or intensity of the colored complex. Of several organic solvents tried for quantitative extraction of the complexes, chloroform was found to be the most suitable solvent, as it was observed that only one extraction was sufficient for the quantitative recovery. The complexes were stable for more than $24 \mathrm{~h}$.

\section{Analytical features}

The ternary complexes obeyed Beer's law in the concentration range of $0.5-5.9$ and $0.5-6.9 \mu \mathrm{g} \mathrm{m}^{-1}$ of $\mathrm{Mo}(\mathrm{VI})$ with molar absorptivity values of $3.28 \times 10^{4}$ and $4.0 \times 10^{4} 1 \mathrm{~mol}^{-1} \mathrm{~cm}^{-1}$ for IPH and PPZ, respectively. Sandell's sensitivity values, as calculated from Beer's law data were found to be 9.8 and 10.9 $\mathrm{ng} \mathrm{ml}^{-1}$ for IPH and PPZ, respectively. Regression analyses of Beer's law plots at their respective $\lambda_{\max }$ values revealed a good correlation ( $r=0.9987$ and 0.9992$)$. Graphs of the absorbance versus the concentration showed low intercept values $(0.02453$ and 0.03188$)$ and slope $(0.1211$ and 0.1437$)$ and are described by a regression equation, $Y=a+b X$ (where $Y$ is the absorbance of a $1 \mathrm{~cm}$ layer, $b$ is the slope, $a$ is the intercept and $X$ is the concentration of the drug in $\mu \mathrm{g} \mathrm{ml}^{-1}$ ), obtained by the least-squares 
Table 2 Determination of molybdenum in alloy steels and soil samples, and comparison with the standard method

\begin{tabular}{|c|c|c|c|c|c|c|c|c|c|}
\hline \multirow{3}{*}{ Sample } & \multirow{3}{*}{ Certified value } & \multirow{2}{*}{\multicolumn{2}{|c|}{$\begin{array}{l}\text { Found }{ }^{\mathrm{a}} \text { by the } \\
\text { proposed method }\end{array}$}} & \multirow{2}{*}{\multicolumn{2}{|c|}{ RSD }} & \multicolumn{4}{|c|}{ Comparison with the standard method } \\
\hline & & & & & & \multicolumn{2}{|c|}{ IPH } & \multicolumn{2}{|c|}{ PPZ } \\
\hline & & IPH & PPZ & IPH & PPZ & $\mathrm{F}$ & $\mathrm{t}$ & F & $\mathrm{t}$ \\
\hline $\operatorname{MSREMo}_{1}{ }^{\mathrm{b}}$ & $4.56 \%$ & $4.57 \%$ & $4.55 \%$ & 1.05 & 0.97 & - & - & - & - \\
\hline $\mathrm{MSREMo}_{2}^{\mathrm{b}}$ & $3.82 \%$ & $3.79 \%$ & $3.80 \%$ & 1.00 & 1.05 & - & - & - & - \\
\hline $\mathrm{BSS}^{\mathrm{c}}$ & $0.85 \%$ & $0.86 \%$ & $0.84 \%$ & 0.91 & 0.91 & - & - & - & - \\
\hline $\mathrm{S}_{1}{ }^{\mathrm{d}}$ & $2.54 \mu \mathrm{g} \mathrm{g}^{-1}$ & $2.55 \mu \mathrm{g} \mathrm{g}^{-1}$ & $2.54 \mu \mathrm{g} \mathrm{g}^{-1}$ & 0.94 & 1.02 & 1.21 & 1.23 & 1.42 & 1.11 \\
\hline $\mathrm{S}_{2}{ }^{\mathrm{d}}$ & $1.91 \mu \mathrm{g} \mathrm{g}^{-1}$ & $1.90 \mu \mathrm{g} \mathrm{g}^{-1}$ & $1.92 \mu \mathrm{g} \mathrm{g}^{-1}$ & 1.02 & 1.07 & 1.34 & 1.11 & 1.31 & 1.12 \\
\hline
\end{tabular}

a. Average of five determinations. b. Obtained from Visweshwaraiah Iron and Steels Ltd., Bhadravati, India. c. Obtained from Bhilai Steels, Bhilai, India. d. Obtained from University of Agricultural Sciences, Dharwad, India.

method. The low relative standard deviation values $(0.88$ and $0.95)$ and the range of error at $95 \%$ confidence level $(0.51$ and 0.62 ) for the analyses of six replicates of $4 \mu \mathrm{g} \mathrm{ml}^{-1}$ of $\mathrm{Mo}(\mathrm{VI})$ indicated good precision and accuracy of the proposed methods.

Stoichiometry of the complexes

The stoichiometry of Mo(V) complexes with IPH or PPZ and $\mathrm{SCN}^{-}$in solution was studied spectrophotometrically by Job's method $^{12}$ of continuous variations and equilibrium shift method. ${ }^{13}$ The results indicated that the mole ratio between $\mathrm{Mo}(\mathrm{V}), \mathrm{SCN}^{-}$and IPH or PPZ was 1:4:1. The solid complexes were isolated from chloroform layer by evaporating on water bath and were analyzed for analytical data. The data correspond to $(\mathrm{IPH} / \mathrm{PPZ} \cdot \mathrm{H})\left[\mathrm{MoO}(\mathrm{SCN})_{4}\right]$. The coordination of IPH/PPZ and $\mathrm{SCN}^{-}$to molybdenum was also confirmed by IR spectral data.

\section{Effect of diverse ions}

The effects of some diverse ions in the determination of $4 \mu \mathrm{g}$ $\mathrm{ml}^{-1}$ of $\mathrm{Mo}(\mathrm{VI})$ in the presence of a number of foreign ions were studied. The results presented in Table 1 clearly indicate that the proposed methods could be effectively applied for the determination of $\mathrm{Mo}(\mathrm{VI})$ when many foreign ions were present in large excess.

Statistical analysis of the results in comparison with the standard methods

The results of the analysis of soil samples were compared statistically by the Students t-test and by the variance ratio Ftest with those obtained by the standard method. ${ }^{3}$ The students t-values at $95 \%$ confidence level did not exceed the theoretical values, indicating that there was no significant difference between the proposed and standard method. It was also noticed that the variance ratio F-values calculated for $p=0.05$ did not exceed the theoretical values, indicating that there was no significant difference between the precision of the proposed methods and the standard method. The results are shown in Table 2.
The proposed methods could be used as alternative methods for the investigation of micro amounts of molybdenum in alloy steels and soil samples, as they are simple and sensitive and free from the interferences of commonly associated substances in these materials.

\section{References}

1. S. N. J. Burgmayer and E. I. Stiefel, J. Chem. Edu., 1985, 62,943

2. Z. Marczenko and R. Lobinski, Pure Appl. Chem., 1991, 63, 1627.

3. E. B. Sandell, "Colorimetric Determination of Traces of Metals", 1959, Interscience, New York, 659.

4. K. N. Thimmaiah, G. T. Chandrappa, and V. C. Sekhar, Mikrochim. Acta, 1986 III, 77.

5. R. Dass and J. R. Mehta, Bull. Chem. Soc. Jpn., 1994, 67, 2103.

6. K. C. Rao, K. V. Reddy, and S. T. Reddy, Proc. Indian Natl. Sci. Acad., Part A, 1993, 59, 449.

7. R. Dass and J. R. Mehta, Bull. Chem. Soc. Jpn., 1994, 67, 999.

8. Y. Chen, Z. Wang, and X. Zhou, Nanjing Huagong Хиеуиап Хиеbao, 1994, 16, 22; Chem. Abstr., 1995, 122 , 45152 e.

9. S. Fan and F. Liang, Lihua Jianyan Huaxue Fence, 1998, 34, 327; Chem. Abstr., 1998, 129, $350297 \mathrm{k}$.

10. L. Tang, C. Liu, and Xiangtan, Lihua Jianyan Huaxue Fence, 1998, 34, 128; Chem. Abstr., 1998, 129, 297632.

11. G. H. Jeffery, J. Bassett, J. Mendham, and R. C. Denney, "Vogel's Text Book of Quantitative Chemical Analysis", Addison Wesley Longman Ltd., 1997, 461.

12. P. Job, Ann. Chim., 1928, 9, 113.

13. H. P. Tarasiewicz, A. Grudriewska, and M. Tarasiewicz, Anal. Chim. Acta, 1977, 94, 435. 